\title{
Endovascular treatment in peripheral arterial disease
}

\author{
A Conti ${ }^{*}$ M Mazzei, F Morrone, P Piro, E Scarcello, S Tarsitano, P Perri, F Intrieri \\ From de Senectute: Age and Health Forum \\ Catanzaro, Italy. 5-7 December 2009
}

Endovascular treatment thirty-three after the first published report on angioplasty, continues to be a rapidly evolving field for the treatment of patients with peripheral arterial disease. A multitude of studies detailing technical improvements and innovative developments have been published. The morphology of a lesion may have an influence on the technical outcome, results at follow up and also risk of treatment.

The TASC (TransAtlantic Inter-Society Consensus) document introduced a classification system that categorised lesions with regard to their accessibility to either percutaneus treatment or surgery. It categorised lesions into four types with: type A lesions ideal for endovascular approach; type B lesions where endovascular approach is still the preferred technique; type $C$ lesions where surgical approach is preferred and type D lesions where surgery is the option of choice.

Today, endovascular practice, percutaneous transluminal angioplasty (PTA) with or without stenting, is used far more frequently for all types of lower extremity occlusive lesions, reflecting the continuing advances in imaging techniques, angioplasty equipment, and endovascular expertise.

The role of endovascular intervention, PTA/ stenting, in the treatment of peripheral arterial disease is also expanding, and its promise of limb salvage and symptom relief with reduced morbidity and mortality makes an attractive alternative to surgery and, as most endovascular interventions are performed on brief hospitalizations, hospital costs are cut considerably. Compared with open surgical procedures, endovascular interventions offer comparable or superior long-term rates of success.

Unit of Vascular and Endovascular Surgery- Annunziata Hospital. A.O. Cosenza, Italy
Published: 19 May 2010

\section{References}

1. Norgren L, Hiatt WR, Dormandy JA, Nehler MR, Harris KA, Fowkes FG, et al: Inter-Society Consensus for the Management of Peripheral Arterial Disease (TASC II). Eur J Vasc Endovasc Surg 2007, 33(Suppl 1):S1-75.

2. Allaqaband S, Kirvaitis R, Jan F, Bajwa T: Curr Probl Cardiol. 2009, 34(9):359-476.

3. Krajcer Z, Howell MH: Update on endovascular treatment of peripheral vascular disease: new tools, techniques, and indications. Tex Heart Inst J. 2000, 27:369-85.

4. P Cao: P. De Rango Endovascular Treatment of Peripheral Artery Disease (PAD): So Old Yet So Far from Evidence! Eur J Vasc Endovasc Surg 2009, 37(5):501-503.

doi:10.1186/1471-2318-10-S1-L8

Cite this article as: Conti et al:: Endovascular treatment in peripheral arterial disease. BMC Geriatrics 2010 10(Suppl 1):L8.
Submit your next manuscript to BioMed Central and take full advantage of:

- Convenient online submission

- Thorough peer review

- No space constraints or color figure charges

- Immediate publication on acceptance

- Inclusion in PubMed, CAS, Scopus and Google Scholar

- Research which is freely available for redistribution

Submit your manuscript at www.biomedcentral.com/submit
C Biomed Central 